Marmara Üniversitesi

İ.̇.B. Dergisi

YIL 2014, CILT XXXVI, SAYI II, S. 327-348

Doi No: 10.14780/iibd.55534

\title{
IS THE EUROPEAN UNION A NORMATIVE POWER? A REAPPRAISAL FOLLOWING THE EUROZONE CRISIS
}

\author{
Beyza Çağatay TEKİN*
}

\begin{abstract}
This article examines the relevance of the Normative Power EU hypothesis by taking the EU's responses in the face of the Eurozone crisis as an empirical case, a litmus test for the EU's normativity claims. Based on a critical, systematic investigation of the EU/IMF financial assistance programmes provided to crisis-hit members, this study argues that neoliberalism embedded in the EU has reached a new stage and has become equipped with very elaborate surveillance and coercion mechanisms. After a five year long disappointing history of neoliberal austerity, serious questions of democratic accountability, solidarity, and deliberative democracy have been raised. Today, the EU is not convincing in its claim to challenge deregulated globalisation and the Normative Power EU argument seems more and more contested than ever.
\end{abstract}

Keywords: EU's international identity, Eurozone crisis, disciplinary neoliberalism, normative power.

JEL Classification: F59, P16.

\section{AVRUPA BİRLIĞİ NORMATİ BİR GÜÇ MÜDÜR? AVRO BÖLGESI KRIZININ ARDINDAN BİR DEĞERLENDİRME}

$\ddot{O}_{z e t}$

Bu makale Avrupa Birliği’ nin uluslararast sistemde bir 'normatif güç' olarak konumlandığı iddiasını Avro Bölgesi krizi bağlamında yeniden değerlendirmektedir. Bu amaçla çalışmada, krizdeki Avro Bölgesi üyelerine yönelik olarak AB ve IMF tarafindan yürütülen finansal yardım ve kurtarma programlarl sistematik olarak, elestirel biçimde incelenmektedir. Makalede, Avro krizinin ardindan gerçekleştirilen reformlarla birlikte $A B$ ' de neoliberalizmin yeni bir aşamaya taşındiğ ve daha gelişmiş gözetim, yaptırım ve baskı mekanizmalarlyla donatıldı ğl savunulmaktadır. Neoliberal reform ve kemer sıkma politikalarlyla geçen bes yıl AB'yi, demokratik hesap verebilirlik, dayanışma ve müzakereci demokrasi konularında ciddi sorunlarla karşı karşıya birakmıştır. Bu gelişmeler AB' nin uluslararast sistemde kendi norm, de ğer ve prensiplerini yaymaya muktedir bir 'normatif güç' veya 'norm koyucu' aktör olduğu iddiasinı bugün her zamankinden daha da tartışmall hale getirmiştir.

Anahtar Kelimeler: AB'nin uluslararası kimliği, Avro Bölgesi Krizi, disipliner neoliberalizm, normatif güç.

JEL Sinıflamast: F59, P16.

Assistant Professor Dr., Galatasaray University, Department of International Relations, btekin@gsu.edu.tr 


\section{Introduction}

In his neo-Gramscian analysis of European integration, Stephen Gill analyses the neoliberal governance in the European Economic and Monetary Union (EMU) from a historical-materialist perspective and explains how the 'new constitutionalism' and accompanying power structures served the institutionalization of 'disciplinary neoliberalism' in Europe. ${ }^{1}$ The present study maintains that the recent restructuring of the economic governance in the European Union (EU), following the onset of the Greek debt crisis in May 2010, and throughout the euro area crisis, represents a quantum leap from 'disciplinary neoliberalism' to 'coercive neoliberalism', accomplished by politico-legal means, and hegemonic discursive practices; hastily, and without any search for a sufficient consensus among European citizens. The EU's institutional and legal responses to the financial turmoil in the euro area, as well as the design of the EU/IMF assistance programmes provided to Greece, Ireland, Portugal, and Cyprus, all reveal that neoliberalism embedded in the EU has reached a new stage, and become equipped with very elaborate surveillance and coercion mechanisms. The new economic governance of the Eurozone is capable of restraining the fundamental rights of EU citizens, constraining policy space of EU governments, and undermining the possibility of democratic contestation of economic policies even further, and in a more effective way. The 'new constitutionalism', which has been operative since the Maastricht Treaty and the establishment of the Economic and Monetary Union was highly instrumental in the construction of a new, more coercive neoliberal economic governance in the euro area from the European Stability Mechanism (ESM), to the 'Six-Pack' and the 'Fiscal Compact'. However, in addition to constitutionalism and modifications in 'hard law', the EU has also developed new, innovative methods based on informal governance, inter-governmentalism and 'soft law', by means of which novel coercion and surveillance mechanisms are designed and successfully imposed. In all these recent developments, a transnational capitalist coalition has been playing an active leadership role in search of more efficient, more direct neoliberal governance and control mechanisms to protect the interests of capital, at the expense of the vested interests of labour.

What are the implications of this emerging mode of 'coercive neoliberalism' for the EU's ideational features, its international identity, and particularly, for the conceptualization of the 'Normative Power EU' (NPEU)? Can we still regard the EU

1 Stephen Gill, "European governance and new constitutionalism: Economic and Monetary Union and alternatives to disciplinary Neoliberalism in Europe", New Political Economy, 3(1), 1998, pp. 5-26. Disciplinary neoliberalism is "a discourse of political economy that promotes the power of capital through extension and deepening of market values and disciplines in social life, under a regime of free enterprise". Stephen Gill, "Constitutionalizing Inequality and the Clash of Globalizations", International Studies Review, 4(2), 2002, p. 47. New constitutionalism can then be defined as the political-legal counterpart to disciplinary neoliberalism, which "legitimates and locks in the power gains of the propertied (capital) by constitutional amendment, international agreements or other juridical-political means". Gill, "Constitutionalizing Inequality", p. 60. See also Stephen Gill, "Globalization, Market Civilization, and Disciplinary Neoliberalism," Millennium-Journal of International Studies, 24(3), 1995, pp. 399-423. 
as 'a normative power', whose actions are guided by a particular set of 'European' or 'Cosmopolitan' norms and values? To what extent is the EU capable of defining 'what passes for normal in world politics', with the power to change norms, standards and prescriptions? The EU's recent economic restructuring and responses to the Euro crisis necessitate a critical examination of the concept of normative power Europe, which has become an almost self-assertive argument. Not only the design, the essence and the structure of the financial assistance programmes but also the way they are enforced and implemented, reflecting neoliberal priorities have strong implications for the NPEU argument. The aim of this article is to illustrate the impact of the EU responses to the debt crisis for the NPEU argument.

By taking the EU's responses in the face of the Eurozone crisis as an empirical case, a litmus test for the EU's normativity claims, this article examines recent reforms in the EU's economic governance, and neoliberal policies forced onto the EU's crisis countries in an attempt to provide answers to the above-stated questions and assess the relevance of the normative power EU hypothesis. More specifically, this study undertakes a critical, systematic investigation of the euro area financial assistance programmes, studying the official texts and documents such as the Letters of Intent, the Memorandum of Economic and Financial Policies, and the Memorandums of Understanding upon which these programmes are based. In addition to these documents signed by Greece, Ireland, Portugal, and Cyprus, and submitted to the relevant EU institutions and the International Monetary Fund (IMF), this study is also informed by publications of these institutions involved in the assistance programmes, as well as reports by the European Parliament, other EU institutions and European non-governmental organisations.

Based on this empirically-oriented, critical analysis of the EU's responses to the Eurozone crisis, this study contends that disciplinary market forces, along with the coercive new constitutionalism, brought the EU to a normative standstill. The fact that the EU included core norms, values and principles in its constitutive Treaties, legal order and policy discourses, long before the present crisis, does not necessarily mean that it applies them accurately, or acts in a normative way, in an ethically good manner. ${ }^{2}$ Despite the core norms, rules and principles upon which the EU's normative power and international identity are assumed to rest are already there, firmly grounded in the acquis communautaire; it was hardly these particular norms embodied in these texts that guided the EU's actions during the present episode of crisis. The making of the austerity programmes imposed on the crisis-hit euro area countries, and the way neoliberal coercion is inflicted do not fit well with the claim that the EU's power relies primarily on non-coercive means and "works through ideas, opinions, and conscience". ${ }^{3}$ Recent developments, particularly the EU's insistence on promoting coercive neoliberalism have also significantly weakened the argument that the EU as an actor has a distinctive ability to change "the norms, standards and prescrip-

2 See Ian Manners, "The normative ethics of the European Union", International Affairs, 84(1), 2008, p. 45.

3 Thomas Diez and Ian Manners, "Reflecting on Normative Power Europe", in F. Berenskoetter, \& M. J. Williams (Eds.), Power in World Politics, New York, Routledge, 2007, p. 175. 
tions of world politics". ${ }^{4}$ This study argues that when the EU/IMF financial assistance programmes are critically scrutinized, it becomes more than clear that they have reproduced well-known neoliberal policy prescriptions emanating from the Washington-based international financial institutions. Instead of shaping the conceptions of normal, therefore, the EU took for granted the hegemonic discourses of the 'primacy of market', or 'competitiveness', and the 'efficiency at all costs' rhetoric, and chose to promote dominant neoliberal policy prescriptions as normal. This not only undermines the EU's normative power, or actorness capacity, but also gives a coup de grâce to the claims that the EU offers an alternative to deregulated, or 'savage' globalization, in the form of a European 'socially responsible' or 'managed' globalization, and a shelter for its Member States, against American-style capitalism.

The next section reviews the concept of Normative Power, sketches some of the core claims of the NPEU argument, placing the emphasis on the EU's normative basis and principles as suggested in the relevant literature. The third section of the article provides an overview of the EU's responses to the Eurozone crisis, from the new institutional framework to the legislative changes in the EU economic governance. This section also analyses the implications of these developments for the NPEU argument, identifying challenges that the EU's fervent adoption of the neoliberal policies brings to its normative basis and principles. The fourth section investigates the specific economic policy conditionality regime of the EU/IMF assistance programmes, questioning to what extent the values, norms and principles promoted remain in compliance with the core norms, values and principles upon which normative power EU argument is based.

\section{Normative basis of the $\mathbf{E U}$}

Although there were many attempts to conceptualize the nature of the EU and the ideational features of EU politics in international relations, it was mainly after Ian Manners' highly-cited, path-breaking article on the concept of Normative Power Europe published in 2002 that the academic interest has become more and more occupied with the ideations, values, principles and norms that inform EU policies and legitimize EU actions. Since then, the claim that the EU is a normative power has been increasingly revisited by International Relations (IR) scholars with the aim of evaluating the validity of the argument. Manners has described the EU as a normative power and claimed that the EU "exists as being different to pre-existing political forms, and that this particular difference pre-disposes it to act in a normative way". 5 The normative power of the EU comes through "a commitment to placing universal norms and principles at the centre of its relations with its member states and the world". 6 This gives the EU a unique, distinct international identity, not comparable to any other ac-

4 Manners, "The normative ethics", p. 45.

5 Ian Manners, "Normative Power Europe: A Contradiction in Terms?", JCMS: Journal of Common Market Studies, 40(2), 2002, p. 242.

6 Ian Manners, "The European Union as a Normative Power: A Response to Thomas Diez", Millennium: Journal of International Studies, 35(1), 2006, p. 176. 
tor in international politics. In this context Manners has argued that the central feature today defining the international identity of the Union "is not what it does or what it says, but what it is". ${ }^{7}$ In this view, the EU is understood as also representing a cosmopolitan polity, which adheres to, and is capable of promoting, a set of particular norms and values in world politics, "because of its particular historical evolution, its hybrid polity, and its constitutional configuration". 8

This formulation of the EU as a normative power has long been endorsed as a salient component of the EU's international role in both the academic and official discourse. ${ }^{9}$ Manners identifies the core 'European' or 'cosmopolitan' norms as peace, liberty, democracy, the rule of law and respect for human rights, with 'minor' norms of social solidarity, anti-discrimination, sustainable development and good governance, which all together constitute the EU's normative basis. ${ }^{10}$ Standing on normative ethics, Manners further developed these nine norms -- normative principles constitutive of the EU -- which define the aims and objectives of the EU in world politics, and guide its actions (see Table 1). ${ }^{11}$

Table 1. The Normative Principles of the EU

\begin{tabular}{|c|c|}
\hline $\begin{array}{c}\text { The EU's normative basis } \\
\text { (Manners, 2002) }\end{array}$ & $\begin{array}{c}\text { The EU's normative principles } \\
\text { (Manners, 2008) }\end{array}$ \\
\hline - Core Norms - & Sustainable peace \\
\hline Peace & Social freedom \\
\hline Liberty & Consensual democracy \\
\hline Democracy & Associative human rights \\
\hline Respect for human rights & Supranational rule of law \\
\hline Rule of law & \\
\hline - Minor Norms - & Social solidarity \\
\hline Social solidarity & Inclusive equality \\
\hline Anti-discrimination & Sustainable development \\
\hline Sustainable development & Good governance \\
\hline Good governance & \\
\hline
\end{tabular}

7 Manners, "Normative Power Europe", p. 252.

8 Ibid., p. 252.

9 Elisabeth De Zutter, "Normative power spotting: an ontological and methodological appraisal", Journal of European Public Policy, 17(8), 2010, p. 1106; Diez and Manners, "Reflecting on Normative Power Europe", p. 176.

10 Manners, "Normative Power Europe", p. 242.

11 Manners, "The normative ethics", pp. 45-60. 
The EU constructs its global leadership role, power and "greater legitimacy"12 through these fundamental norms which have been inserted firmly into the main legal documents, EU Law and treaties such as the Treaty on European Union (TEU), the Charter of Fundamental Rights of the EU or the Lisbon Treaty. The EU exercises its normative power through diplomatic means and the use of soft power only, without any recourse to coercion, economic or military; and the distinctively European, or Cosmopolitan values, norms and principles diffuse through contagion, transference, informational or procedural diffusion and cultural filter. ${ }^{13}$ In the view of the proponents of the NPEU hypothesis, this is almost an innate right and a destiny, as Manners states confidently, "The EU has been, is and always will be a normative power in world politics". ${ }^{14}$ The normative dimension of the EU thus also corresponds to a form of 'ideological power' which enables the EU 'to shape conceptions of 'normal' in international relations". 15

The EU's normative power crucially depends on the full respect of and commitment to these norms and principles in both its internal and external relations. The credibility of the EU as a normative power does not rely solely on its external relations with the third parties but also on the nature of its relations with its member states. In order to assess the empirical relevance of the NPEU argument therefore, it is not satisfactory to only consider the EU's foreign policy or external relations with the third countries. The EU's relations with its member countries should also critically be addressed. It is important that in its relations with the member countries, the EU has been acting in accordance to the normativity claims particularly in the areas such as social rights and freedoms, equality, solidarity and non-discriminations. Otherwise claims about the EU as a normative power are nothing but "just cheap talk". ${ }^{16}$

Another substantial indicator of normative power is to act in accordance with legal principles, self-binding through law, "a system of action that makes it possible to implement moral duties or commitments". ${ }^{17}$ The cosmopolitan nature of this conceptualization of the EU's international identity also requires normative power to be exercised credibly and consistently; truth conditions of this identity claim residing on "consistency between internal policies and external prescriptions and actions". ${ }^{18}$

12 Manners, "Normative Power Europe", p. 244. See also Richard G. Whitman, "The neo-normative turn in theorising the EU's international presence", Cooperation and Conflict, 48(2), 2013, pp. 171-193.

13 Manners, "Normative Power Europe", pp. 244-245.

14 Manners, "The normative ethics", p. 45.

15 Manners, "Normative Power Europe", p. 239.

16 Erik O. Eriksen, “The EU- a cosmopolitan polity?", Journal of European Public Policy, 13(2), 2006, p. 262.

17 Helene Sjursen, “The EU as a 'normative' power: how can this be?”, Journal of European Public Policy, 13(2), 2006, p. 244.

18 Kalypso Nicolaidis and Dimitri Nicolaidis, "The EuroMed beyond Civilisational Paradigms", in Emanuel Adler, Federica Bicchi, Beverly Crawford and Raffaelle Del Sarto (Eds.), The Convergence of Civilisations: Constructing a Mediterranean Region, Toronto, University of Toronto Press, 2006, p. 348. 
Apart from that, a normative power should be perceived as 'legitimate' in the principles it promotes, in a fair, coherent, and consistent way. ${ }^{19}$ In other words, not only is normative power diffused by "living by virtuous example" 20 , but it also dissolves if it undergoes a lack of legitimacy in principles, or when it fails to secure consistency and coherence in its actions. Finally, and above all, considering that self-prescriptions only make sense when the audience buys the argument, the assessment of the observers also counts, both from within, and from the outside. ${ }^{21}$

\section{Eurozone bailout and the NPEU hypothesis}

The eruption of the Greek debt crisis in spring 2010 and the eventual contagion of the economic turmoil to other Eurozone members have triggered a swift change in the EU's economic governance. A series of substantial reforms has been realized over the course of the past few years, from the 'Euro Plus Pact' and the 'Fiscal Compact', to the 'Six-Pack' and the 'Two-pack'.22 The ultimate aim of these new rules and legislations was to provide the euro area with the necessary fiscal policy convergence, in a way to mitigate the risk of a new financial crisis in the foreseeable future. With the recent reforms the EU aimed at eradicating the major flaws in the original design of the European Monetary Union, and thus, coming into terms with the 'first sin' of initiating the monetary union without any meaningful step towards a fiscal union. With the automatic sanctions mechanisms, and more effective additional supranational control and monitoring mechanisms, these economic governance reforms aimed to bring a lasting end to the economic turmoil in the euro area.

19 Ian Manners, "The EU's Normative Power in Changing World Politics", in André Gerrits (Ed.), Normative Power Europe in a Changing World: A Discussion, Hague, Netherlands Institute of International Relations, 2009, p. 12.

20 Manners, "The normative ethics", p. 56.

21 See De Zutter, "Normative power spotting”, pp. 1106-1127.

22 Approved by twenty-three EU countries in March 2011, the Euro Plus Pact is an intergovernmental arrangement which requires signatory states to anchor a broad range of fiscal policy reforms, including pension reforms, in their national legislations. In December 2011, the EU leaders agreed on the 'Treaty on Stability, Coordination and Governance in the Economic and Monetary Union', also known as the 'Fiscal Compact' (signed in March 2012). With the aim of enhancing fiscal policy supervision in the Euro area, the Fiscal Compact introduced an automatic sanctions mechanism to be applied to euro area member states failing to comply with the agreed budgetary rules. In addition to these two intergovernmental agreements, the EU also realized two sets of legislative reforms. Entered into force in December 2011, the Six-Pack comprises five Regulations and one Directive which initiated a new process for preventing and correcting macroeconomic imbalances in the Eurozone. Built on the Six-Pack, and adopted in May 2013, the Two-Pack aims to enhance fiscal policy convergence across the euro area countries, mainly by enabling the European Commission to issue an opinion on compliance of a draft budget prior to its submission to national parliaments. Both of these legislative reforms aiming at completing the structural reform process of the Stability and Growth Pact (SGP) are now part of the European Semester. 
These reforms however, resulted in a considerable decay in the EU member states' ability to decide on specific fiscal policy measures to support specific targets such as employment creation, or economic growth. Taken together, the Euro Plus Pact, the Fiscal Compact, the Six-Pack, and the Two-Pack thus reduced the policy autonomy of member states, as well as the democratic control over economic policy making significantly. The continuing neoliberal restructuring of the EU's economic governance is stricter than the original EMU in many respects, particularly in constricting the established democratic control processes over economic policy and decision-making.

On a more practical level, the EU's response to the Eurozone crisis was to develop a new mechanism -- namely the European Financial Stability Facility (EFSF) and the European Stability Mechanism (ESM) -- by means of which a series of emergency financial support measures can be provided to Eurozone member economies. In this new framework for emergency financial support, the EU initiated a number of financial assistance programmes, often referred to as EU 'bailout packages'. These financial assistance programmes were jointly funded by the EU (two thirds of the funds) and the IMF (one third of the funds). These programmes were designed and managed by the 'Troika' -- the tripartite body composed of the European Commission, the European Central Bank (ECB) and the International Monetary Fund. With respect to the size of financial funds associated, the EU/IMF rescue programmes are larger (and in the case of Greece, significantly larger) than similar IMF stand-by deals signed by Turkey, Brazil, Mexico or Argentina in the previous decades. ${ }^{23}$ The terms of lending (i.e. the rates of interest) were typically above -- i.e. actually more favourable to the lender than -- those dictated by financial markets on the date of funding. ${ }^{24}$

The EU's preferences, quasi-legal restructuring, and changing relations with the crisis-hit euro area Member States in the last couple of years have strong implications for the NPEU argument. This analysis inclines us to think that the NPEU argument today seems to be less and less convincing, and more contested and contradictory than ever. This can be seen, first and foremost, in the lack of transparency in the decision-making processes during the design and implementation of the EU/ IMF assistance programmes, and in the weak democratic accountability of associated institutions.

The EU/IMF assistance programmes were negotiated in the name of the EU by the European Commission, acting "in liaison with the ECB and, wherever possible, together with the IMF". ${ }^{25}$ The Commission's decisions concerning the details of the

23 Jean Pisani-Ferry et al., "EU-IMF assistance to euro-area countries: an early assessment", Bruegel Blueprint Series, No. 19, 2013, p. 30.

24 Due to the insistence of European political leaders for overly strict lending criteria, credits to the euro area member states "could only be provided at penalty rates", that is, at rates much higher than the prevailing market rate, reaching as high as 400 basis points above Euribor. Pisani-Ferry et al., "EU-IMF assistance to euro-area countries", p. 67.

25 Treaty establishing the European Stability Mechanism (ESM), 2012, p. 29, http://www. eurozone.europa.eu/media/migrated/596968/treaty_establishing_the_esm_2012_final. pdf, Accessed (18.06.2014). 
bilateral loans were declared as based on Ecofin Council recommendations, but have been, in practice, shaped exclusively by the Eurogroup, an informal body composed of euro area finance ministers. ${ }^{26}$ In all EU/IMF assistance programmes, disbursement of financial aid is made conditional on the fulfilment of specific criteria, which are subject to continual monitoring and quarterly reviews to be held by the Commission, and the $\mathrm{IMF}^{27}$ The structural policy conditionality inherent in the programmes is declared to be decided 'jointly' by the three members of the Troika. However, no further information about how exactly negotiations and decision-making processes are held, and the division of labour within the Troika, was provided.

\subsection{Lack of transparency and the problem of weak accountability}

Apart from the extremely vague agency structure, and the imprecision in the manner through which authority is being dispersed in the name of the Union, there was also a severe lack of transparency in the making and implementation of the EU/ IMF assistance programmes. The way negotiations were held in reality between the Troika and the relevant Member State seeking assistance, as well as the degree to which a crisis-hit Member State was capable of influencing negotiations, were unclear and lacking in transparency. ${ }^{28}$ In its resolution of 20 November 2012 the European Parliament called the EU institutions which are members of the Troika to secure full transparency, stronger democratic legitimacy, and highest standards of accountability at both the national and Union level ${ }^{29}$; however, no serious action for this end has been taken yet. The lack of transparency in the making and implementation of the EU/IMF programmes was of such magnitude that on 21 November 2013 the European Parliament sent a 'questionnaire' to institutions involved in the Troika, and euro area Member States under the EU/IMF assistance programmes, in the framework of the drafting of an "Own initiative report evaluating the structure, the role and operations of the Troika actions in euro area programme countries". ${ }^{30}$ On the claim that

26 European Parliament, "Report on the enquiry on the role and operations of the Troika (ECB, Commission and IMF) with regard to the euro area programme countries", Committee on Economic and Monetary Affairs, 2014, http://www.europarl.europa.eu/sides/ getDoc.do? pubRef=-//EP//NONSGML+REPORT+A7-2014-0149+0+DOC+PDF+V0// EN, Accessed (18.06.2014).

27 It should be emphasized at this level of analysis that although conditionality is claimed to be a negotiated compromise between the Troika and Member State governments, it is an imposition on those latter by all means, since there was no other genuinely viable alternative for the programme countries other than bowing to the demands of the lenders to get access to the desperately needed funds.

28 European Parliament, "Report on the enquiry on the role and operations of the Troika", p. 5.

29 http://www.europarl.europa.eu/sides/getDoc.do?type=TA\&reference=P7-TA-2012-0430 \&language $=\mathrm{EN}$, Accessed (18.06.2014).

30 European Parliament, "Questionnaire supporting the own initiative report evaluating the structure, the role and operations of the 'troika' (Commission, ECB and the IMF) actions in euro area programme countries", 2013, http://www.europarl.europa.eu/docu- 
"many citizens in Europe are sensing a lack of accountability and transparency of the working methods of the Troika" 31 the European Parliament directed 29 very specific questions -- plus 9 additional questions to the Member States -- in the questionnaire, aiming to shed more light on decision and policy-making processes, and issues of accountability, as well as to uncover the principles and assumptions guiding the financial assistance programmes.

The European Parliament sent the questionnaire to the IMF, the European Council, the European Commission, the ECB, the Eurogroup and the ministries of finance and central banks of Greece, Ireland, Portugal and Cyprus. Responses to this questionnaire are quite revelatory in observing how the lack of transparency leaves accountability of the parties extremely blurred, making legitimacy of decisions highly questionable. Broadly speaking, these institutions either declined to fill in the questionnaire, denying any involvement with, or accountability for, the implementation of the assistance programmes altogether, or provided only incomplete answers to the very precise questions. In the first instance, the IMF refused to fill in the questionnaire and respond to the questions, claiming that it is not publicly accountable by reason of its statuses not permitting it to "appear formally before, or report in writing to national or European Parliaments", a feature the European Parliament "regrets". 32 In a similar manner, the European Council also declined to fill in the European Parliament's questionnaire, renouncing any involvement with Troika decisions and the design of the programmes in a letter written by Herman Van Rompuy who declared, "as President of the European Council, I am not involved in the interaction of these institutions with programme countries or in the review of their reports and assessments". 33

The ECB, -- one of the two EU institutions within the Troika -- answered the questionnaire only on a selective basis, and avoided providing precise information regarding the criteria through which reform priorities have been identified, as well as about the assumptions guiding policy decisions. In regard to the very clear, technical question about 'fiscal multipliers' used to forecast debt sustainability, the ECB, for example, responded only by commenting that this issue has been "overly simplified", while "reality is much more complicated and nuanced". ${ }^{34}$ In response to the question "What was the modus operandi leading to the adoption of draft programmes?" the

ment/activities/cont/201401/20140114ATT77313/20140114ATT77313EN.pdf, Accessed (18.06.2014).

31 http://www.europarl.europa.eu/committees/en/econ/subject-files.html?id=20140114CDT77307, Accessed (18.06.2014).

32 European Parliament, "Report on the enquiry on the role and operations of the Troika", p. 18.

33 European Council, "European Council response to the questionnaire of the European Parliament on the troika (Herman Van Rompuy Letter)", 2013, http://www.europarl.europa. eu/document/activities/cont/201401/20140114ATT77309/20140114ATT77309EN.pdf, Accessed (18.06.2014).

34 European Central Bank, "ECB response to the questionnaire of the European Parliament on the troika", 2014, p. 2, http://www.ecb.europa.eu/pub/pdf/other/140110_ecb_response_troika_questionnaireen.pdf, Accessed (18.06.2014). 
ECB also gave a somewhat evasive answer, claiming that "it would be impossible to summarize in a few lines the extensive and detailed macroeconomic analysis" that is already outlined in the Memorandums of Understanding, and the periodic staff reports by the European Commission and the IMF ${ }^{35}$ The ECB provided no precise information regarding specific policies it implements under the assistance programmes, either. With regard to its role in "imposing conditions in exchange for liquidity support" (question 26), the ECB provided no explanation, answering that "the ECB decides on its monetary policy in full independence". ${ }^{36}$ Regarding the questions about the design and democratic accountability of the programmes, the ECB commented that "in terms of specific measures for specific countries, it would be more appropriate for the Eurogroup to respond". 37

The European Commission, while answering the more general questions in detail, did not to provide worthwhile clarifications about the assumptions guiding the economic policy conditionality of the programmes. Just like the ECB, for specific questions about the programme implementation, decision-making, and accountability issues, the Commission attributed responsibility to the Ecofin and Eurogroup in its responses to the questionnaire. ${ }^{38}$ The Eurogroup, on the other hand, responded to the 29 very specific questions with a four-and-a-half page letter responding to "some of the broader issues raised" only, claiming that it is up to the programme countries and Troika institutions to provide answers, as they, "themselves are best placed to answer many of your specific questions". 39 The European Parliament's attempt to overcome the lack of transparency surrounding the design and implementation of the euro area assistance programmes thus ended in a dialogue des sourds. The question of effective public accountability of the euro area assistance programmes remained unanswered.

\section{2. 'Informal governance' and the problem of self-binding through law}

The European Parliament's incapacity in gaining insight -- let aside in gaining control -- over the decision-making, and authority-dispersion processes within the Troika reveals one major problem with the EU's responses to the Eurozone crisis: the problem of democratic control. Not only was information kept behind closed doors, and a genuine debate on alternative ways of coping with the crisis was blocked, but also democratic channels of decision-making were almost totally sidestepped in the making of the euro area programmes, and during the course of recent neoliberal re-

35 Ibid., p. 2.

36 Ibid., p. 10.

37 Ibid., p. 4.

38 European Commission, "European Commission response to the questionnaire of the European Parliament on the troika", http://www.europarl.europa.eu/document/activities/ cont/201401/20140114ATT77315/20140114ATT77315EN.pdf, Accessed (18.06.2014).

39 Eurogroup, "Eurogroup response to the questionnaire of the European Parliament on the troika”, 2014, http://www.europarl.europa.eu/document/activities/cont/201401/20140114ATT77339/20140114ATT77339EN.pdf, Accessed (18.06.2014). 
forms. The EU's responses are thus tainted by a strong inclination towards strengthening the authority of the independent, technocratic bodies of EU bureaucracy, such as the ECB. Meanwhile parliamentary oversight of policy-making was highly limited at the national level and absent at the EU level. ${ }^{40}$ In the case of Portugal, for example, policy conditionality of the austerity package was not even ratified by the national parliament. This attitude of avoiding deliberation, social dialogue and democratic control is a general problem faced in the implementation of the programmes, as a recent report by the European Trade Union Confederation (ETUC) has revealed. In its report based on its affiliates' responses to a questionnaire about the functioning of the Troika, presented at a hearing of the European Parliament on 14 February 2014, ETUC claimed that Troika representatives avoided dialogue with social partners, choosing to respond "with a 'set response', replying with 'generalities' or in an elusive way, while being absolute in their demands by saying "you have to do this or the other"", 41

The lack of democratic control, deliberation, and involvement of the masses can be best seen in the EU's avoidance to put any of the recent decisions to a public referendum. In the fear of rejection, none of the recent institutional or legislative reforms have been put to referendum (with the exception of Irish referendum on Fiscal Compact), despite the fact that such major reforms in European integration require treaty revisions, which, in turn, need to be ratified either by parliamentary votes or referendums. ${ }^{42}$ The EU political leaders were 'wise enough' to take the necessary lesson from the French, Dutch and Irish 'No' to the European Constitution; considering that what motivated the French No were people's concerns with the 'Bolkestein directive', and 'the too excessive neoliberalism embedded in the European Constitution'. The avoidance of referendums and delegation of authority to weakly accountable, 'technocratic' institutions have been successful in effectively restraining democratic contestation of neoliberal austerity policies during the past few years. ${ }^{43}$ These strategies the EU adopted in times of an emergency, however, have produced inconsistency in the pursuit of norms, and problems of democratic legitimacy, all undermining the truth claims of the EU's normative power.

Actually, it can be admitted that in the face of the Eurozone crisis the EU had a serious difficulty of self-binding through law, and failed to fully respect the established rules, procedures and modalities. In a chain of instances when responding to the financial turmoil in the euro area the EU sidestepped the agreed legal norms and the existing procedures and conventions of the Union. These practices have important implications for the EU's normative power, since self-binding through law is a strong indicator of normative power. As Sjursen correctly points out, it is self-binding through law which would "ensure consistency in the application and pursuit of nor-

40 Henk Overbeek, "Sovereign Debt Crisis in Euroland: Root Causes and Implications for European Integration”, International Spectator, 47(1), 2012, pp. 44-45.

41 ETUC, "The Functioning of the Troika: A Report from the ETUC", European Trade Union Confederation, Brussels, 2014, p. 4.

42 Frank Schimmelfennig, "European Integration in the Euro Crisis: The Limits of Postfunctionalism", Journal of European Integration, 36(3), 2014, p. 333.

43 Schimmelfennig, "European Integration in the Euro Crisis", pp. 333-334 
ms" ${ }^{44}$ The NPEU argument requires legal commitments be respected consistently at all times, (including times of crisis and distress) as this is what brings legitimacy of actions.

In the first instance, delegation of power to supranational institutions such as the Commission and the ECB involved a series of breaches of the agreed legal norms, and established procedures, of the Union. The very participation of the ECB in the decision-making processes related to 'budgetary', 'fiscal', and 'macroeconomic' policies of programme countries as a member of the Troika is the most widely asserted breach of the EU's legal norms. ${ }^{45}$ This is primarily because the ECB needed an "informal expansion" of its mandates in order to be able to adopt such a function in the bailout programmes. ${ }^{46}$ The present function of the ECB within the Troika goes definitely beyond the agreed legal norms constitutive of the EMU, since the ECB's mandate is confined by the Treaty on the Functioning of the European Union (TFEU) to 'monetary policy', and 'financial stability' exclusively. ${ }^{47}$ Similarly, the Commission's involvement in the Troika is also in close contradiction with its "normal role, which is to act as an independent principal protecting the EU interest and ensuring the implementation of EU rules within the limits established by the Treaties". ${ }^{48}$ Furthermore, as highlighted by the European Parliament, the Commission has no legal competence in participating in decision making processes in Member States' wages, pensions, or social policy. ${ }^{49}$ Thus, by taking an active part in the design and execution of austerity measures forced upon Greece, Ireland, Portugal and Cyprus, the ECB and the Commission went far beyond their duties and responsibilities specified in the existing legal structure of the EU. The assertion of EU-level executive power by the Eurogroup, which is an informal body whose role is not specified in EU's primary law is just another clear breach of the agreed legal norms and rules of the Union. ${ }^{50}$

A major reason for why the EU failed in so many instances of self-binding through law is the absence of an appropriate legal basis, in the absence of which, most of the change has to be accomplished outside the main body of EU primary law, controverting established practices, and principles grounded in the acquis communau-

44 Sjursen, "The EU as a "normative" power", p. 244.

45 European Parliament, "Report on the enquiry on the role and operations of the Troika", p. 17.

46 See Schimmelfennig, "European Integration in the Euro Crisis”, p. 335.

47 European Parliament, "Report on the enquiry on the role and operations of the Troika", p. 17.

48 Ibid., p. 17.

49 Ibid., p. 17.

50 European Parliament, "Report on the enquiry on the role and operations of the Troika", p. 16. Also see Ioannis Katsaroumpas, "EU Bailout Conditionality as a De Facto Mode of Government: A Neoliberal 'Black Hole' for the Greek Collective Labour Law System?", Labour Law Research Conference, Pompeu Fabra University, Barcelona, 13-15 June 2013, http://www.upf.edu/gredtiss/_pdf/2013-LLRNConf_Katsaroumpas.pdf, Accessed (18.06.2014). 
taire. It can be said that the EU was somewhat obliged to search for -- and actually succeeded in -- finding new, innovative ways through which it can collaborate with the IMF for setting up the euro area rescue packages. Contrary to what would be expected from a normative power, however, 'informal' governance has become more than an exception but a rule during the Eurozone crisis, making the decision-making processes increasingly blurred, resulting in democratic accountability and legitimacy problems.

The prevalence of informal governance is performed by a strategy of combining 'hard law' with 'soft law', and 'constitutionalism' with 'bilateralism/intergovermentalism'. This new mode of governance of the EU does not present an example of genuinely 'deliberative' form of intergovernmentalism, or 'deliberative intergovernmentalism' as suggested by Puetter ${ }^{51}$, either. This is because 'deliberation' necessitates an open debate, devoid of hierarchical power relations. It is extremely difficult to claim that such a deliberative process has taken place in the present case, not only because of the lack of transparency and inadequate flow of information, or because of the denial of accountability -- and responsibility -- by the Troika institutions, but also because of the domination of political debates and decision-making processes by the larger, wealthier, and economically more powerful Member States. The Euro area programmes, and current restructuring in the EU's economic governance were led, and dominated by these larger, 'core' members of the EU, and in all these recent developments "the voices of the southern, smaller members are not heeded, contrary to what would be expected in a post-national polity". 52

\section{On the EU's ability of changing norms, standards and prescriptions: whose norms and values are these after all?}

Loan or policy conditionality is by far the most salient feature of the EU/IMF assistance programmes, which started prior to the very first disbursement of financial support in all cases. ${ }^{53}$ Conditionality regime of the EU/IMF assistance programmes has strong implications for the NPEU argument. This is primarily because policy conditionality is a transference of norms, values and idea(l)s, and also of a particular ideology. In this sense, conditionality regime of the assistance programmes is very similar to the EU's own 'democratic conditionality' imposed on accession coun-

51 Uwe Puetter, "Europe's deliberative intergovernmentalism: the role of the Council and European Council in EU economic governance”, Journal of European Public Policy, 19(2), 2012, pp. 161-178.

52 Beyza Ç. Tekin, "Rethinking the Post-National EU in Times of Austerity and Crisis", Mediterranean Politics, 19(1), 2014, p. 35.

53 In the case of Greece, programme conditionality even involved EU (and IMF) demands for political arrangements to seek control over election results to secure the adjustment programmes. All the major political parties were forced to sign a letter confirming that they will respect the policy conditionality regime of the proposed programme, on the eve of the May 2012 general elections in Greece. See Leigh Phillips, "Future Greek governments must be bound to austerity strategy", EUobserver, 21 November 2011, https://euobserver. com/economic/114344, Accessed (18.06.2014). 
tries. ${ }^{54}$ It is therefore crucial to understand which particular set of norms and values are transferred somewhat forcibly under the stringent loan conditionality regime of the EU/IMF assistance programmes. Only after such an inquiry can it be possible to critically assess the EU's distinctive ability to set norms, standards and prescriptions -- one of the core claims of the normative power Europe argument.

Structurally, the EU/IMF assistance programmes are enacted in the very same way of a typical IMF stand-by agreement, i.e. they all started by a 'Letter of Intent' and a Memorandum of Economic and Financial Policies (MEFP) submitted to the IMF by the Minister of Finance and the Governor of the Central Bank of the borrower country, summarising the present state of the economic and financial conditions, and the urgent needs of the economy, as well as drawing the contours of the structural and economic policy measures to be implemented if financial support is secured. These documents do not only institute in legal terms an economic relation and a distinct conditionality relation simultaneously 55 , but they also tell us much about the "superior' economic policy vision the creditor countries dictate on the programme countries. In that sense, the policy conditionality forms a hierarchy of economic policy visions and norms, between those recommended by the Troika, and the ones which have been already at use in programme countries, decided as a result of the relevant national democratic processes.

In the EU/IMF assistance programmes the disbursement of credit tranches is made conditional on the adoption of a set of very detailed economic policies and structural reforms, framed as 'indispensable' for the attainment of specific macroeconomic objectives. In this conditionality regime, specific performance criteria, economic policies, and benchmark structural reforms are defined in an exhaustive manner, and loan-receiving country governments are provided with a rigid timetable for meeting these targets before the specified deadlines. ${ }^{56}$ Here, it should be noted that the loan conditionality inscribed in the above documents corresponds to the more stringent form of conditionality regimes implemented under typical IMF stand-by agreements. ${ }^{57}$

54 For a detailed analysis of the EU bailout conditionality, see Katsaroumpas, "EU Bailout Conditionality", pp. 1-41. For a discussion of how a set of specific norms and values are transferred under the EU democratic conditionality, see Frank Schimmelfennig and Ulrich Sedelmeier, "Governance by conditionality: EU rule transfer to the candidate countries of Central and Eastern Europe", Journal of European Public Policy, 11(4), 2004, pp. 661679.

55 Katsaroumpas, "EU Bailout Conditionality", p. 4.

56 For a detailed analysis of this 'policy-based' conditionality approach, see Mohsin S. Khan and Sunil Sharma, "IMF Conditionality and Country Ownership of Programs", IMF Working Paper No. 01/142, IMF Institute, 2001, pp. 23-25.

57 Here, it is important to note that 'strict' conditionality is demanded by the EU, rather than the IMF, based on the former's presumption that the legitimacy of any EU bailout in the euro area can be secured if, and only if, strict conditionality is enforced. See Philomila Tsoukala, "Narratives of the European Crisis and the Future of (Social) Europe", Texas International Law Journal, 48(2), 2013, p. 253. 
The EU/IMF assistance programmes indicate remarkable rhetorical, and macroeconomic, and structural policy continuity with the previous IMF stand-by agreements. In each of the programmes loan conditionality limited the policy space substantially, demanding stringent fiscal consolidation, drastic cuts in social benefits and services, including pensions, along with restrictive wage policies and neoliberal reforms in national pension and collective wage bargaining systems, and in state structure. Expansive deregulation in the labour market and in the provision of health and education services, public expenditure re-prioritization, and mass privatisation were among the other main elements of the conditionality regime of the euro area programmes. These policies and reforms correspond to a particular set of neoliberal policy prescriptions often referred to as the 'Washington Consensus', a policy straightjacket which has long been widely criticised in development economics with regard to its ineffectiveness in promoting sustainable development and growth, and for deteriorating social texture and undermining country ownership of adjustment programs. ${ }^{58}$ Despite the fact that as a result of growing criticism an adjusted version of this neoliberal policy vision has come to be seriously considered, however, no significant departure from the older paradigm of the Washington Consensus can be observed in the case of the EU/ IMF assistance programmes. ${ }^{59}$ This is because no, or just too little attention has been paid for easing the detrimental economic and social effects of extreme austerity measures. ${ }^{60}$ Likewise, poverty and inequality issues were simply hardly mentioned in any of the Memorandums of Understanding or other assistance programme documents. ${ }^{61}$ Poverty alleviation was not made part of any of the EU/IMF assistance programmes, and no poverty reduction mechanisms were foreseen (perhaps, to some extent, with the exception of the Greek programme). ${ }^{62}$

58 For this particular economic policy vision and norms emanating from the Washington-based international financial institutions, see John Williamson, "What Washington Means by Policy Reform," in J. Williamson (Ed.), Latin American Adjustment: How Much Has Happened?, Washington, Institute for International Economics, 1990, pp. 5-38 and John Williamson "Democracy and the 'Washington Consensus"”, World Development, 21(8), 1993, pp. 1329-1336.

59 Often referred to as the 'augmented', or 'post-' Washington Consensus, the adjusted version refers to a set of second generation neoliberal reforms which aims to mitigate the deteriorating impact of structural adjustment programmes on the weaker members of the society, placing more emphasis on poverty alleviation, and inequality reduction, through targeted poverty reduction schemes, and social safety nets. See Dani Rodrik, "Goodbye Washington Consensus, Hello Washington Confusion? A Review of the World Bank's Economic Growth in the 1990s: Learning from a Decade of Reform", Journal of Economic Literature, 44(4), 2006, pp. 973-987.

60 European Parliament, "Report on the enquiry on the role and operations of the Troika", p. 15.

61 See André Sapir et al., "The Troika and financial assistance in the euro area: successes and failures", European Parliament, Economic and Monetary Affairs Committee Study, PE 497.764, February 2014, p. 6.

62 Sapir et al., The Troika and financial assistance in the euro area”, p. 17-18. 
On balance, the very same 'one-size-fits-all' approach of the standard IMF structural adjustment programmes has been reproduced. Extreme austerity measures are framed as bitter medicine compulsory to cure the sickness. In the 'selling' of the programmes, in their public statements and interviews, Troika officials employed the same rhetoric in which 'competitiveness' and the purest neoliberal prescriptions of the Washington Consensus are marketed as a cure-all medicine, for all, and every problem, in the euro area. Discourses of the 'primacy of the market' and 'market imperatives', as well as 'restitution of competitiveness', and 'efficiency at all cost', came forth with an unprecedented fervour, undermining the idea of a Delorsian 'Social Europe'.

Most of these specific economic policy recommendations and structural reforms are difficult to fit in the NPEU argument. This is primarily because a genuine social solidarity has not been achieved, not only because of the loan conditionality, strict monitoring, excessive austerity demands, and the 'penalty' terms of lending, but also because "the burden has not been shared among all who acted irresponsibly and that the protection of bondholders was seen as an EU necessity in the interests of financial stability". ${ }^{63}$ Restrictive wage policies and decentralisation of collective bargaining were by far the most controversial measures projected by the Troika, as these resulted in the suspension of the interests of the working classes in a direct and unprecedented way. ${ }^{64}$ These policies dictated by the Troika are widely criticized as open breaches of the EU's agreed legal norms, and constitutive norms, values, and principles. The European Trade Union Confederation criticized the too-restrictive wage policies and decentralization in collective bargaining for having significantly limited the autonomy of trade unions to negotiate wages, and declared these measures as not fitting well with the EU Charter of Fundamental Rights. ${ }^{65}$ On November 2012, the International Labour Organization (ILO) Committee on Freedom of Association criticized the widespread deficit of social dialogue in Greece, and declared that the new procedures favouring decentralized bargaining represent "a weakening of freedom of association and collective bargaining contrary to the principles of Conventions Nos 87 and 98".66 The Committee also called the Greek government to review, without delay, and in dialogue with the social partners, the application of new procedures such as the special sub-minima wages for young workers and the long-term unemployed. ${ }^{67}$

A decision by the European Social Committee of the European Social Charter also condemned the minimum wage arrangements and restrictive wage policies of the

63 European Parliament, "Report on the enquiry on the role and operations of the Troika", p. 20.

64 These measures go from the 1 euro reduction in the hourly minimum wages in Ireland, to differential minimum wage reductions, forced early retirement, and a full-blown dismantling of the collective bargaining, and unemployment and labour protection system in Greece. See Sapir et al., "The Troika and financial assistance in the euro area", pp. 1-87.

65 ETUC, "The Functioning of the Troika", pp. 2-10.

66 ILO, "365th Report of the Committee on Freedom of Association-Case No. 2820", International Labour Office, Geneva, 2012, p. 272.

67 Ibid., p. 270. 
Greek programme as "discriminatory on basis of age and thus violating the non-discrimination clause in the Preamble of European Social Charter". ${ }^{68}$ These criticisms were so widely pronounced both from the outside, and within the EU that the European Parliament called Troika to ensure that the programmes fully conform to:

"[...] the objectives of the European Union, i.e. the promotion of employment and improved living and working conditions, so as to make possible their harmonisation while the improvement is being maintained, as well as proper social protection, dialogue between management and labour, the development of human resources with a view to lasting high employment and the combating of exclusion, as stated in Article 151 TFEU". 69

The European Parliament has also criticized health system reforms and cuts in social benefits in programme countries for harming people's access to basic health services, and thus for violating the Charter of Fundamental Rights of the EU, or the provisions of the constitutive Treaties, especially Article 168 (7) of the TFEU.$^{70}$

\section{Conclusion}

After a five year long disappointing history of neoliberal austerity, continuing restructuring in the EU's economic governance and the Troika regime, serious questions of democratic accountability, transparency, solidarity, and deliberative democracy have been raised. The strict conditionality of the bailout agreements has clearly shown that the EU/IMF programmes were 'business as usual', rather than genuinely 'European' or 'Cosmopolitan' acts of solidarity. While the Troika involved in disintegrating what has remained from 'Social Europe', neither the European Parliament, nor the European Court of Justice, or any other supranational, or national institution could secure deliberative democracy, democratic control and accountability, and legitimacy of decision-making procedures. They all failed utterly; just like democratic control mechanisms failed before elsewhere, in the 'developing world', when faced with similar policy conditionality and neoliberal reforms.

The crisis helped those observers of the European Union, both from within, and from the outside, to see 'the emperor's new clothes', the naked truth that the EU lacks the ideational capacity to offer a viable alternative to globalization. The EU did not only give a kiss of life to the wobbling 'Washington Consensus', but also seriously deteriorated its self-image of a shelter to its members in the face of American-style, deregulated, 'savage' capitalism. The European rescue plan has shown us that an alternative, EU-style 'managed globalization' simply does not exist, nowhere other than in the discourses of European political elites. In the past few years, the Troika regime in the euro area explicitly declared all policy alternatives to neoliberalism irrational,

68 Katsaroumpas, "EU Bailout Conditionality", p. 30.

69 European Parliament, "Report on the enquiry on the role and operations of the Troika", p. 20.

Ibid., p. 12. 
almost illegal, insisting that there can't be any credible alternative to neoliberal austerity and reforms.

This study of the EU's preferences, and actions, during the Eurozone crisis shows that the new design of the EMU, following the recent institutional reforms, legal modifications and informal structures, clearly contradicts many principles of the concept of normative power Europe. EU's responses in the face of crisis do not reflect what the EU has promised to its citizens, the creation of an alternative form of polity capable of dealing with negative effects of neoliberal globalism. Today, the EU is not convincing in its claim to challenge deregulated globalisation and the NPEU argument seems contradictory and contested.

\section{Acknowledgement}

The author acknowledges financial support by the Scientific and Technological Research Council of Turkey (TÜBİTAK) provided in the framework of BİDEB 2219 Programme. 


\section{References}

DE ZUTTER, Elisabeth, "Normative power spotting: an ontological and methodological appraisal”, Journal of European Public Policy, 17(8), 2010, pp. 11061127.

DIEZ, Thomas and MANNERS, Ian, "Reflecting on Normative Power Europe", in F. Berenskoetter, \& M. J. Williams (Eds.), Power in World Politics, New York, Routledge, 2007, pp. 173-188.

ERIKSEN, Erik O., “The EU- a cosmopolitan polity?”, Journal of European Public Policy, 13(2), 2006, pp. 252-269.

EUROGROUP, "Eurogroup response to the questionnaire of the European Parliament on the troika", 2014 http://www.europarl.europa.eu/document/activities/ cont/201401/20140114ATT77339/20140114ATT77339EN.pdf, Accessed (18.06.2014).

EUROPEAN CENTRAL BANK, "ECB response to the questionnaire of the European Parliament on the troika", 2014. http://www.ecb.europa.eu/pub/pdf/other/140110_ecb_response_troika_questionnaireen.pdf, Accessed (18.06.2014).

EUROPEAN COMMISSION, "European Commission response to the questionnaire of the European Parliament on the troika", http://www.europarl.europa.eu/document/activities/cont/201401/20140114ATT77315/20140114ATT77315EN. pdf, Accessed (18.06.2014).

EUROPEAN COUNCIL, "European Council response to the questionnaire of the European Parliament on the troika (Herman Van Rompuy Letter)", 2013, http:// www.europarl.europa.eu/document/activities/cont/201401/20140114ATT77309/20140114ATT77309EN.pdf, Accessed (18.06.2014).

EUROPEAN PARLIAMENT, "Questionnaire supporting the own initiative report evaluating the structure, the role and operations of the 'troika' (Commission, ECB and the IMF) actions in euro area programme countries", 2013, http:// www.europarl.europa.eu/document/activities/cont/201401/20140114ATT77313/20140114ATT77313EN.pdf, Accessed (18.06.2014).

EUROPEAN PARLIAMENT, "Report on the enquiry on the role and operations of the Troika (ECB, Commission and IMF) with regard to the euro area programme countries", Committee on Economic and Monetary Affairs, 2014, http://www.europarl.europa.eu/sides/getDoc.do?pubRef=-//EP//NONSGML+REPORT+A7-2014-0149+0+DOC+PDF+V0//EN, Accessed (18.06.2014)

ETUC, "The Functioning of the Troika: A Report from the ETUC", European Trade Union Confederation, Brussels, 2014, http://www.etuc.org/sites/www.etuc. org/files/press-release/files/the_functioning_of_the_troika_finaledit2.pdf, Accessed (18.06.2014)

GILL, Stephen, “Globalization, Market Civilization, and Disciplinary Neoliberalism', Millennium-Journal of International Studies, 24(3), 1995, pp. 399423. 
GILL, Stephen, "European governance and new constitutionalism: Economic and Monetary Union and alternatives to disciplinary Neoliberalism in Europe", New Political Economy, 3(1), 1998, pp. 5-26.

GILL, Stephen, "Constitutionalizing Inequality and the Clash of Globalizations”, International Studies Review, 4(2), 2002, pp. 47-65.

ILO, "365th Report of the Committee on Freedom of Association-Case No. 2820", International Labour Office, Geneva, 2012, http://www.ilo.org/wcmsp5/groups/public/---ed_norm/---relconf/documents/meetingdocument/ wcms_193260.pdf, Accessed (18.06.2014).

KATSAROUMPAS, Ioannis, "EU Bailout Conditionality as a De Facto Mode of Government: A Neoliberal 'Black Hole' for the Greek Collective Labour Law System?", Labour Law Research Conference, Pompeu Fabra University, Barcelona, 13-15 June 2013, http://www.upf.edu/gredtiss/_pdf/2013-LLRNConf_Katsaroumpas.pdf, Accessed (18.06.2014).

KHAN, Mohsin S., and SHARMA, Sunil. "IMF Conditionality and Country Ownership of Programs”, IMF Working Paper No. 01/142, IMF Institute, 2001.

MANNERS, Ian, "Normative Power Europe: A Contradiction in Terms?", JCMS: Journal of Common Market Studies, 40(2), 2002, pp. 235-258.

MANNERS, Ian, “The European Union as a Normative Power: A Response to Thomas Diez", Millennium: Journal of International Studies, 35(1), 2006, pp. 167-180.

MANNERS, Ian, "The normative ethics of the European Union", International Affairs, 84(1), 2008, pp. 45-60.

MANNERS, Ian, “The EU's Normative Power in Changing World Politics", in André Gerrits (Ed.), Normative Power Europe in a Changing World: A Discussion, Hague, Netherlands Institute of International Relations, 2009, pp. 9-24.

NICOLAIDIS, Kalypso and NICOLAIDIS, Dimitri, “The EuroMed beyond Civilisational Paradigms", in Emanuiel Adler, Federica Bicchi, Beverly Crawford and Raffaelle Del Sarto (Eds.), The Convergence of Civilisations: Constructing a Mediterranean Region, Toronto, University of Toronto Press, 2006, pp. 337-377.

OVERBEEK, Henk, "Sovereign Debt Crisis in Euroland: Root Causes and Implications for European Integration", International Spectator, 47(1), 2012, pp. $30-48$.

PHILLIPS, Leigh, "Future Greek governments must be bound to austerity strategy", EUobserver, 21 November 2011, https://euobserver.com/economic/114344, Accessed (18.06.2014).

PISANI-FERRY, Jean, SAPIR , André and WOLFF, Guntram B. "EU-IMF assistance to euro-area countries: an early assessment", Bruegel Blueprint Series, No.19, 2013. 
PUETTER, Uwe, "Europe's deliberative intergovernmentalism: the role of the Council and European Council in EU economic governance", Journal of European Public Policy, 19(2), 2012, pp. 161-178.

RODRIK, Dani, “Goodbye Washington Consensus, Hello Washington Confusion? A Review of the World Bank's Economic Growth in the 1990s: Learning from a Decade of Reform”, Journal of Economic Literature, 44(4), 2006, pp. 973 987.

SAPIR, André, WOLFF, Guntram B., DE SOUSA, Carlos and TERZI, Alessio, "The Troika and financial assistance in the euro area: successes and failures", European Parliament, Economic and Monetary Affairs Committee Study, PE 497.764, February 2014.

SCHIMMELFENNIG, Frank, "European Integration in the Euro Crisis: The Limits of Postfunctionalism”, Journal of European Integration, 36(3), 2014, pp. 321-337.

SCHIMMELFENNIG, Frank and SEDELMEIER, Ulrich, "Governance by conditionality: EU rule transfer to the candidate countries of Central and Eastern Europe", Journal of European Public Policy, 11(4), 2004, pp. 661-679.

SJURSEN, Helene, “The EU as a 'normative' power: how can this be?", Journal of European Public Policy, 13(2), 2006, pp. 235-251.

TEKIN, Beyza Ç., "Rethinking the Post-National EU in Times of Austerity and Crisis", Mediterranean Politics, 19(1), 2014, pp. 21-39.

Treaty establishing the European Stability Mechanism (ESM), 2012, http://www.eurozone.europa.eu/media/migrated/596968/treaty_establishing_the_esm_2012_ final.pdf, Accessed (18.06.2014)

TSOUKALA, Philomila, "Narratives of the European Crisis and the Future of (Social) Europe”,Texas International Law Journal, 48(2), 2013, pp. 241-266.

WILLIAMSON, John, "What Washington Means by Policy Reform," in J. Williamson (Ed.), Latin American Adjustment: How Much Has Happened?, Washington, Institute for International Economics, 1990, pp. 5-38.

WILLIAMSON, John, "Democracy and the "Washington Consensus"”, World Development, 21(8), 1993, pp. 1329-1336.

WHITMAN, Richard G., "The neo-normative turn in theorising the EU's international presence", Cooperation and Conflict, 48(2), 2013, pp. 171-193. 